\title{
Formal Approaches in Controlling White Collar Crime: The Criminal Justice System and the Regulatory System
}

\author{
Dr. Julak Lee \\ Associate Professor, Department of Security Management, Kyonggi University \\ Republic of Korea \\ Email: julaklee@kgu.ac.kr
}

Doi:10.5296/ jpag.v5i4.8604 URL: http://dx.doi.org/10.5296/ jpag.v5i4. 8604

\begin{abstract}
Unlike ordinary street crime, there are two formal systems of controlling white-collar crime. These systems are the criminal justice system and the regulatory system. The criminal justice system controls white-collar crime by using criminal law whereas the regulatory system depends mainly on administrative law and uses various ways such as financial penalties, product recalls, and warnings to control white-collar crime. In this paper two formal justice systems of white collar crime have been discussed. Although the criminal justice system, which is the traditional means to control white-collar crime, can be a strong way to control white-collar crime, it has some limitations. That is, the criminal justice system is difficult to apply to the corporate world and it is the reactive response against white collar crime. In contrast, although the regulatory system is the weak way to control white-collar crime, it has some strength. That is, the regulatory system is a proactive response against white collar crime and it can apply to the corporate as well as natural persons. The characteristics of the regulatory system make it better equipped to situational crime prevention theory compared to the criminal justice system.
\end{abstract}

Keywords: White Collar Crime, Criminal Justice System, Regulatory System, Situational Crime Prevention 


\section{Introduction}

Unlike ordinary street crime, there are two formal systems of controlling white-collar crime. These systems are the criminal justice system and the regulatory system. The criminal justice system controls white-collar crime by using criminal law whereas the regulatory system depends mainly on administrative law and uses various ways such as financial penalties, product recalls, and warnings to control white-collar crime.

In this paper, first, I will discuss how these two systems differ in their approach to controlling harmful behavior. Second, I will present their respective strengths and weaknesses as they relate to white-collar crime control. Finally, I will discuss which of these two systems would be better equipped to use situational crime prevention theory (SCPT) against white-collar crime.

\section{The Differences between the Two Systems in Controlling Harmful Behaviors}

There are some differences between the criminal justice system and the regulatory justice system. First, there is a difference in the purpose of the two systems. The purpose of the criminal justice system is to prevent and control the people who may violate the law whereas the purpose of the regulatory justice system is to make the offender comply with the law (Benson \& Simpson, 2009). Second, there is a difference in the legal interventions to control harmful behaviors. The criminal justice system has criminal law as its intervention whereas the regulatory system has multiple legal interventions such as administration law, civil law, and criminal justice law. Third, there is a difference in the nature between the two systems. The criminal justice system is reactive whereas the regulatory justice system is proactive (Benson \& Simpson, 2009). That is, the criminal justice system focuses on the punishment of the offender after the illegal behavior. However, the regulatory justice system focuses on prevention of the illegal behavior. For example, the regulatory system may require a practitioner to hold a degree or certification to provide a particular service. The requirements can play an important role in preventing the illegal behaviors by blocking the legal access of potential offenders.

Fourth, there is a difference in the nature of the control between the two systems. The criminal justice system is oppressive. For example, if a CEO of any company embezzles some money from the company, he or she may be imprisoned after a conviction. In contrast, the control of the regulatory system is more persuasive than the criminal justice system (Benson \& Simpson, 2009). For example, if a regulatory law requires a permit for the sale of alcohol, the regulation can be regarded as persuasion rather than warning for punishment. Fifth, there is a difference in the investigative agencies and the jurisdiction of the court between the two systems. The police investigate, and the trial take place in the criminal courts in the criminal justice system. In contrast, the special agency's inspector investigates, and the trial take place in the administrative courts in the regulatory justice system.

Sixth, there is a difference in the legal standards between the two systems. The criminal justice system requests beyond reasonable doubt to convict an individual. That is, in the criminal justice system a prosecutor must prove and convince to the jury and judge that an 
individual did illegal behavior knowing its illegality whereas the regulatory system did not request legal standards as high as criminal justice system. That is, whether an individual knows his or her illegal behavior does not have an impact on a sanctions against him or her in regulatory system. Seventh, there is a difference in the sanction targets between the two systems. The criminal justice system mainly focus on controlling individuals whereas the regulatory system mainly focus on controlling organizations.

Finally, the perspective of the criminal justice system is monolithic whereas the perspectives of the regulatory system are multiple. That is, the perspectives of the regulatory system are divided into the justice model, the rational-legal model, the economic model, and the conflict model (Frank \& Lombness, 1988). The justice model regards the purpose of regulation as the social control against economic institution. The rational-legal model regards the regulatory law as the response of legislators on a series of social problems. The economic model evaluates whether the benefit of the regulation exceeds the cost of the regulation. The conflict model regards the regulatory system as power competition between groups. The perspectives influence the evaluation of strengths and weaknesses about regulatory system.

\section{Strengths and Weaknesses of the Criminal Justice System}

\subsection{Strengths}

First, the criminal justice system can be a stronger means to block white-collar crimes than the regulatory justice system. White-collar offenders are much more afraid of going to prison than street offenders (Braithwaite \& Geis, 2001). Thus, if white-collar crimes are punished by the criminal justice system, white-collar crimes of potential offenders can be strongly prevented. Second, the criminal justice system is less influenced by corporates than the regulatory system is. That is, sometimes the criminal justice system can be more effective for controlling white-collar crime because the criminal justice system shortens corporate leaders' discretion. Hence, Braithwaite (1981-1982) argues that while economism (using performance standards and taxing harms) as a form of regulation for corporate conduct has some advantages (e.g., flexibility and innovation), legalism should continue to be used as the main method of enforcement.

\subsection{Weaknesses}

First, it is difficult to investigate and prosecute white-collar crime (Benson \& Cullen, 1998; Benson, 2001a; Braithwaite \& Geis, 2001). In the case of corporate crime, which occupies most of white-collar crime, many people take part in the decision of the company. The people take part in "concerted ignorance" (Katz, 1979) to avoid criminal penalties. "Concerted ignorance" means that organization leaders intentionally avoid some kind of learning to reduce the punishment against them. As a result, an individual responsibility is often replaced by the company's responsibility (Fisse \& Braithwaite, 1993). Hidden nature and complexity of white-collar crime makes investigating and prosecuting white-collar crime difficult (Schudson et al., 1984). For example, strong corporate criminals continuously use the complexity of law, organization, and books to avoid intervention of the criminal law (Braithwaite, 1981-1982). Also, a successful conviction for corporate crime often leads to an 
appeal that can overturn the original conviction (Benson \& Simpson, 2009). To avoid the appeal, in most cases, the government prosecutes small companies rather than big companies (Cullen et al., 2006).

Second, if a criminal defendant is not an individual but a corporate, the criminal justice system is difficult to apply. Although criminal law gives responsibility to corporates which are regarded as natural persons, it is difficult for prosecutors to proceed with lawsuits against corporates in the court (Benson \& Cullen, 1998). Thus, the punishment by criminal law just focuses on small new companies instead of big companies (Cullen et al., 2006). Finally, expansion of criminal law to prevent corporate crimes may face the resistance of corporates. The enlargement of criminal law may provoke the challenge of corporates. If law is felt illegal or unnecessarily restricting or too harsh, corporates may fight the law through disobedience and challenge (Benson \& Simpson, 2009).

\section{Strengths and Weaknesses of the Regulatory System}

\subsection{Strengths}

The regulatory system has several strengths compared to the criminal justice system. First, the regulatory justice system can contribute more than the criminal justice system to prevent the damage of white-collar crime. This is because the regulatory system focuses on the prevention of harms instead of responding to the offenders (Benson \& Simpson, 2009). Second, the regulatory system is appropriate for controlling corporate crimes that occupy most of white-collar crimes. This is because the regulatory system can control the corporates as well as natural persons. For example, the regulatory system can impose a certain amount of fines on the company instead of a specific person in case of the wastewater discharge of the company. In this case, the government does not need to have difficulty to find a specific person who is responsible for the wastewater discharge.

Third, judging from the perspective of the rational-legal model, the regulatory system is effective in solving social problems. For example, occupational safety regulations achieved a great effect on the safety of workers. That is, the rate of injured workers has been reduced by one third compared to 50 years ago (Cullen et al., 2006). Finally, judging from the perspective of the economic model, regulations such as performance standards can minimize social harms and ensure responsible behaviors of corporates without the court process (Braithwaite, 1981-1982). Corporates try to reduce social harms regardless of the basis in law because it is more profitable. For example, if a tax increase is imposed in proportion to the number of people injured in a work place, corporates will try their best not to lose the hands of workers during their work through additional training efforts.

\subsection{Weaknesses}

The regulatory system has some weaknesses. First, it is weaker than the criminal justice system in controlling crime (Benson \& Simpson, 2009). This is because it does not have the strong enforcement mechanisms compared to the criminal justice system. Second, the regulatory system can be more influenced than the criminal justice system by the corporate (Benson \& Simpson, 2009). The corporate can have an impact on regulatory policies and 
procedures. It can block the achievement of the original purpose of the regulatory system. Third, judging from the justice model, the regulatory system has a small number of inspectors to monitor corporates and too much discretion in applying law. Also, the sanctions are not clear and strict to deter corporate offenders.

Fourth, judging from the rational-legal model, it is difficult to balance between regulatory law and other social strategies to solve social problems. Also, corporates do not comply easily because the government makes a legal action into an illegal action without agreement of corporate (Makkai \& Braithwaite, 1994). Fifth, judging the conflict model, although the regulatory system emerges to protect the weak, it may change to protect the profits of corporate owners. For example, the working time limit is regulated to protect the health and safety of workers at first. However, it can be used as means not to pay much money to workers. That is, business owners may employ inexpensive part-time workers instead of expensive full-time workers based on the working time limit. Also, it can be ineffectual if the regulations are conducted without an agreement between stakeholders (Benson \& Simpson, 2009). Finally, judging from the economic model, the regulatory system is not cost-effective (Shover, Clelland, \& Lynxwiler, 1986). That is, without regulations, social goods can be provided in lower price. Also, regulations are difficult to calculate cost and benefit.

\section{Which Is Better for Situational Crime Prevention?}

SCPT tries to prevent crimes through changing opportunity structures. Thus, opportunity structures of white-collar crime should be understood to apply SCPT strategies to the crime. Also, three things should be considered to understand the opportunity structure of white-collar crime. First, we should focus on "highly specific forms of crime" (Benson \& Madensen, 2007, p 614). It is necessary to apply SCPT because the same kind of crime is committed by using various modus operandi. For example, in case of health care fraud, there are various fraudulent ways such as health care fraud committed by a physician, a psychiatrist, a pharmacist, and organizations (Geis et al. 1985; Sparrow, 1996; Loyd, 2005; Payne, 2013). Each health care fraud has a different opportunity structure. Second, SCPT stresses the manipulation of the immediate environment. Thus, understanding the immediate environment of the crime is necessary to understand opportunity structure. In connection with this, Brantingham and Brantingham (2001) explained that criminal opportunity structure includes offender, target, place, mechanism, and special situation. Also, routine activity theory (RAT) assumes that crime occurs when an offender meets a target at a place without guardian, handler, and place manager (Felson, 2002). For white-collar crime, a transactional network should be regarded as a place instead of physical place (Vaughan, 1982; Eck \& Clarke, 2003). Finally, rational choice of white-collar offenders should be considered to apply situational crime prevention. White-collar offenders may do more rational choice than ordinary street offenders. This is because white-collar offenders are more educated and suffer less from alcohol and drugs (Braithwaite \& Fisse, 1990). Thus, for white-collar crime, SCPT measures can be conducted more effectively. However, it should be considered that white-collar offenders can adjust interventions and avoid them continuously without investigation (Benson \& Madensen, 2007). 


\section{Mll Macrothink}

Journal of Public Administration and Governance

ISSN 2161-7104

2015, Vol. 5, No. 4

The criminal justice system is not appropriate for changing the opportunity structure of white-collar crime. The reasons are as follows. First, the criminal justice system is not appropriate for blocking highly specific forms of crime. It is impossible to regulate various forms of white-collar criminal behaviors with criminal law. For example, it is impossible to make a criminal law for each type of health care fraud. Second, SCPT stresses the manipulation of the immediate environment but the criminal justice system is too far to block the immediate criminal opportunity structure. For example, harsher sanctions imposed by the criminal justice system may increase the risks of potential offenders. However, it is inefficient considering the costs because it is too far from immediate decision making of potential offenders (Benson \& Madensen, 2007). Following SCPT, increasing risk of detection during and shortly after committing crime is more efficient. Empirical evidence has supported it over time (Pratt et al., 2005). Finally, white-collar offenders are more rational than ordinary street criminal offenders. Hence, white-collar offenders will soon apply the interventions by the criminal justice system and avoid the punishments. Although the criminal justice system can change depending on white-collar offenders' reactions, it will take a long time to make criminal law that punishes the changed behaviors of white-collar offenders.

On the contrary, the regulatory system is better equipped with SCPT compared to the criminal justice system. The reasons are as follows. First, the regulatory system is appropriate for blocking highly specific forms of crime. For example, health care fraud by physicians can be blocked by using techniques from SCPT. The principle of increasing the risk of detection can be used. That is, more thorough examination on Medicare (or Medicaid) reimbursement can be possible through strengthening the education of Medicare (or Medicaid) staffs. Also, the principle of reducing the rewards can be used. That is, if Medicare (or Medicaid) staffs find suspicious reimbursement, they can examine the case thoroughly delaying processing the case as much as possible.

Second, the regulatory system is appropriate for manipulation of the immediate environment because the goal of the regulatory system is compliance rather than punishment. For example, if physicians who have committed health care fraud over two times are regulated not to request reimbursement funds anymore, the manipulated environment blocks the physicians' similar offending. Finally, the regulatory system can make new regulations fast because the regulatory system is flexible. Thus, when white-collar offenders adjust to interventions and then try to avoid the interventions, new regulations can be made fast to cope with the situation. In sum, the regulatory system can be better equipped to use SCPT against white collar crime than the criminal justice system. This is because the regulatory system better corresponds with opportunity perspective compared to the criminal justice system (Benson \& Simpson, 2009). In opportunity perspective, the most effective way to control crime is to change opportunity structures to be less attractive to potential offenders. The regulatory system can create obstacles for the white-collar offenders, thus making it more difficult for them to commit crimes.

\section{Conclusion}

So far, two formal justice systems of white collar crime have been discussed. Although the 
criminal justice system, which is the traditional means to control white-collar crime, can be a strong way to control white-collar crime, it has some limitations. That is, the criminal justice system is difficult to apply to the corporate world and it is the reactive response against white collar crime. In contrast, although the regulatory system is the weak way to control white-collar crime, it has some strengths. That is, the regulatory system is a proactive response against white collar crime and it can apply to the corporate as well as natural persons. The characteristics of the regulatory system make it better equipped to SCPT compared to the criminal justice system.

\section{References}

Benson, M. L. (2001a). Investing corporate crime: Local responses to fraud and environmental offenses, Western State University Law Review, 28, 87-116.

Benson, M. L. (2001b). Prosecuting corporate crime: Problems and constraints. Pp. 281-291 in Crimes of Privilege: Readings in White-Collar Crime, edited by Neal Shover and John P. Wright. New York: Oxford University Press.

Benson, M. L., \& Cullen, F. T. (1998). Combating Corporate Crime: Local Prosecutors at Work. Boston, MA: Northeastern University Press.

Benson, M. L., Cullen, F. T., Maakestad, W. J. (1990). Local prosecutors and corporate crime. Crime and Delinquency, 36, 356-372.

Benson, M. L. \& Madensen. T. D. (2007). Situational crime prevention and white-collar crime. Pp. 609-626 in H. N. Pontell \& G. Geis. (eds.), International Handbook of White-Collar and Corporate Crime, New York: Springer.

Benson, M. L., \& Simpson, S. S. (2009). White-Collar Crime: An Opportunity Perspective. New York: Routledge.

Braithwaite, J. (1981-1982). The limits of economism in controlling harmful corporate conduct. Law \& Society Review, 16(3), 481-504.

Braithwaite, J., \& Fisse, B. (1990). On the plausibility of corporate crime control. Advances in Criminological Theory, 2, 15-37.

Braithwaite, J., \& Geis, G. (2001). On theory and action for corporate crime control. Pp.361-380 in Crimes of Privilege: Readings in White-Collar Crime, edited by Neal Shover and John Paul Wright. New York: Oxford University Press.

Cullen, F. T., Cavender, G., Maakestad, W. J., \& Benson, M. L. (2006). Corporate Crime Under Attack: The fight to Criminalize Business Vionence. Newark, NJ: LexisNexis Matthew Bender.

Eck, J. E., \& Clarke, V. (2003). Classifying common police problems: A routine activity approach. Crime Prevention Studies, 16, 7-39.

Felson, M. (2002). Crime and Everyday Life. Thousand Oaks: Sage Publications. 


\section{Macrothink}

Journal of Public Administration and Governance ISSN 2161-7104 2015, Vol. 5, No. 4

Fisse, B, \& Braithwaite, J. (1993). Corporations, Crime, and Accountability. Cambridge, New York: Cambridge University Press.

Frank, N., \& Lombness, M. (1988). Controlling Corporate Illegality: The Regulatory Justice System. Cincinnati, Ohio: Anderson.

Geis, G., Jesilow, P., Pontell, H., \& O'Brien, M. J. (1985). Fraud and abuse of government medical benefit programs by psychiatrists. American Journal of Psychiatry, 142(2), 231-234.

Katz, J. (1979). Concerted ignorance: The social construction of cover-Up. Urban Life, 8, 295-316.

Loyd, L. (2005). GlaxoSmithKline to pay $\$ 150.8$ million to Settle Justice Department Allegations. Philadelphia Inquirer. September 20, 2005.

Makkai, T., \& Braithwaite, J. (1994). The dialectics of corporate deterrence. Journal of Research in Crime and Delinquency, 31, 347-373.

Payne, B. K. (2013). White-Collar Crime. SAGE Publications, Inc.

Pratt, T. C., Cullen, F. T., Blevins, K. R., Daigle, L. E., \& Madensen, T. D. (2006). The empirical status of deterrence theory: A meta-anlysis. Pp. 367-395 In Taking Stock: The Empirical Status of Criminological Theory-Advances in Criminological Theory, Volume 15, Editors Francis T. Cullen, John Paul Wright, and Kristie R. Blevins. New Brunswick, NJ: Transaction Publishers.

Schudson, C. B., Onellion, A. P., \& Hochstedler, E. (1984). Nailing an omelet to the wall: Prosecuting nursing home homicide. Pp. 131-146 in Corporations As Criminals, edited by Ellen Hochstedler. Beverely Hills, CA: Sage.

Shover, N., Clelland, D. A., \& Lynxwiler, J. (1986). Enforcement or Negotiation. Albany, NY: State University of New York Press.

Sparrow, M. K. (1996). License to Steal: Why Fraud Plagues America's Health Care System. Boulder, Colo: Westview Press.

Vaughan, D. (1982). Transaction systems and unlawful behavior. Social Problems, 29, 373-379. 